WITOLD KLINGER

\title{
DWAJ ZAPOMNIANI KRZEWICIELE ANTYKU W POLSCE XX WIEKU ${ }^{1}$
}

Abstract. Klinger Witold, Dwaj zapomniani krzewiciele antyku w Polsce XX wieku (Two Forgotten Propagators of Antiquity in 20th-Century Poland).

The article is devoted to the life and work of two Polish classical philologists, Rudolf Szczękowski and Henryk Jakubanis, who played a significant role in the history of Polish science.

Keywords: Rudolf Szczękowski; Henryk Jakubanis; classical philology in Poland; University of Kiev; Warsaw University; Catholic University of Lublin.

Ludzie, o których mówić tu zamierzam, bliscy są sobie nie tylko zamiłowaniami i wykreśloną przez nie pracą, ale także pochodzeniem i czasem działalności. Obaj przybyli do Polski z rozproszenia polskiego: jeden z Ukrainy przeddnieprzańskiej, drugi zaś aż z brzegów dalekiej Wołgi, obaj przyszli na świat w tym samym 1879 roku i w tym samym mniej więcej czasie czynni być przestali: jeden oderwany od życia i pracy przez śmierć, drugi przez ciężkie kalectwo, uniemożliwiające bliższe obcowanie z ludźmi. Pierwszy to Rudolf Szczękowski, dobrze znany w Warszawie i poza nią nauczyciel języków starożytnych, lektor greki na Uniwersytecie Warszawskim, drugi to Henryk Roman Jakubanis, profesor filozofii starożytnej w Uniwersytecie Katolickim w Lublinie, poprzednio zaś w na rosyjskim Uniwersytecie Kijowskim i w powstałym w 1916 r. Polskim Kolegium Uniwersyteckim² w Kijowie. Każdy z nich zasłużył na wdzięczną pamięć społeczeństwa polskiego.

\footnotetext{
${ }^{1}$ Do druku na podstawie maszynopisu z odręcznymi poprawkami Autora przygotował Henryk Paprocki.

${ }^{2}$ Polskie Kolegium Uniwersyteckie - szkoła wyższa, powołana w Kijowie w 1917 r. w miejsce dotychczasowych Wyższych Polskich Kursów Naukowych (powołanych w tymże roku). Przestało działać w 1919 r. Por. Zasztowt 2007: 285-312; Korzeniowski 2009: 229-251 (wszystkie przypisy są autorstwa Henryka Paprockiego).
} 
Rudolf Szczękowski urodził się w roku już wymienionym (dnia nie pamię$\operatorname{tam})^{3}$ w Białej Cerkwi ${ }^{4}$ na Kijowszczyźnie jako syn oficjalisty, zatrudnionego w administracji rozległych dóbr hrabiów Branickich ${ }^{5}$. Wcześnie straciwszy ojca i matkę, wychowuje się w domu wuja, który dbając o pozostałe sieroty, oddaje je po kolei do znajdującego się w tymże mieście gimnazjum. Warto tu przypomnieć, że powstało ono w 1847 r. jako kontynuacja polskiego gimnazjum podolskiego w Winnicy ${ }^{6}$, które jako jedyne ze szkół dawnych nie zostało po 1839 r. zamknięte, mimo dokonanej rusyfikacji słabo przez rząd finansowane, znajdowało się w głębokim upadku. Skorzystał z tego smutnej pamięci syn hrabiego Branickiego i dzięki swym stosunkom u dworu otrzymał - w zamian za wybudowanie własnym kosztem obszernego dla szkoły gmachu - zgodę władz na przeniesienie do Białej Cerkwi gimnazjum podolskiego wraz z przekazaną mu cenną biblioteką pojezuicką. Dając możność oficjalistom wychowywać dzieci na miejscu, Braniccy poszli za przykładem Potockich, którzy w osobie Bolesława ${ }^{7}$, syna Szczęsnego, jeszcze w 1838 r. własnym kosztem wznieśli gmach dla gimnazjum w Niemirowie. O stosunkach, jakie w Białej Cerkwi aż do końca XIX w. panowały, udzielił mi na krótko przed śmiercią Zygmunt Opatowicz ${ }^{8}$, adiunkt naszego uniwersytetu, cennych informacji, które pozostają w zupełnej zgodzie $\mathrm{z}$ materiałem zebranym przez Jadwigę Wojciechowską-Żywultową w książce pamiątkowej Biała Cerkiew. Książka pamiątkowa białocerkiewian 9 . Uprawnia

${ }^{3}$ Teczka osobowa Rudolfa Szczękowskiego nie zachowała się w zespole akt MWRiOP (informacja AAN w Warszawie z 17 IX 2018 r.).

${ }^{4}$ Biała Cerkiew (ukr. Біла Церква) - miasto na Ukrainie, największe w obwodzie kijowskim, nad rzeką Roś, w odległości 84 km na południe od Kijowa, siedziba administracyjna rejonu białocerkiewskiego. Miasto (osada) za czasów Ruski Kijowskiej nazywało się Jurijew. Jego początki sięgają IX w. Od 1363 r. Biała Cerkiew należała do Wielkiego Księstwa Litewskiego, a od 1569 r. do województwa kijowskiego Korony Królestwa Polskiego. W 1880 r. miasto liczyło 8961 prawosławnych, 9808 żydów i 412 katolików.

${ }^{5}$ Braniccy - nazwisko członków dwóch polskich rodów arystokratycznych: starszego używającego herbu Gryf i młodszego używającego herbu Korczak. Ostatnim z rodu Gryfitów był Jan Klemens Branicki, właściciel pałacu Branickich w Białymstoku.

${ }^{6}$ Winnica (ukr. Вінниця) - miasto w środkowej części Ukrainy, nad Bohem, na wschodnim Podolu, stolica rejonu i obwodu winnickiego. W czasie zaboru rosyjskiego w mieście istniało Winnickie Gimnazjum Państwowe, w którym do upadku powstania listopadowego większość kadry stanowili polscy profesorowie, a wykłady odbywały się głównie w języku polskim

${ }^{7}$ Bolesław Potocki herbu Pilawa (1805-1893), zwany „Bobiche” - syn Stanisława Szczęsnego i Zofii Potockiej, jego trzeciej żony. Prawdopodobnie biologiczny syn Szczęsnego Jerzego, pasierba swojej matki. Ziemianin, fundator szkół, ochmistrz dworu rosyjskiego. Został pochowany w Petersburgu.

${ }^{8}$ Zygmunt Opatowicz (1886-1956) - lektor języka francuskiego, zmarł 16 marca 1956 r. został pochowany w Poznaniu na Cmentarzu Junikowo (pole 10, kwatera 2, rząd A, miejsce 9).

${ }^{9}$ Wojciechowska-Żywultowa 1939. 
mnie jedno i drugie do twierdzenia, że choć wszystkie szkoły na kresach były po $1830 \mathrm{r}$. terenem zakusów rusyfikacyjnych, to nigdzie nastawienie antypolskie nie rzucało się tak jaskrawo w oczy, jak w Białej Cerkwi. Dość powiedzieć, że jeszcze w 1899 r. nowo przysłany dyrektor gimnazjum Samojłowicz mógł do zebranej w sali polskiej przeważnie młodzieży, powiedzieć: „Nie kalajcie mową polską murów szkoły rosyjskiej" ${ }^{10} \mathrm{i}$ w zgodzie z tym nauczyciel greki Lebiedinczew koledze memu z Niemirowa ${ }^{11}$, który kończył w Białej Cerkwi gimnazjum, Żaboklickiemu kazał po grecku przetłumaczyć zdanie: „Obym nigdy nie mówił po polsku!”, a gdy ten był w kłopocie, sam mu powiedział: „Eithe me pote poloniroimi!" i wlepił jedynkę ${ }^{12}$. Ten napór prawie szturmowy spotykał się tam z wytrwałym oporem, ośrodkiem którego była tajna biblioteka polska, która, przenoszona z miejsca na miejsce, znalazła prawdziwie bohaterskiego obrońcę: kiedy żandarmi, co ją w końcu wyśledzili, opieczętowali szafy i odeszli, uczeń VII klasy Skarżyński pieczęcie zerwał, listy i papiery zniszczył, i samobójstwo popełnił. Z tej to szkoły w Białej Cerkwi wyszli ludzie tej miary, co sławny malarz Jan Stanisławski ${ }^{13}$, historyk szkolnictwa w Polsce Ludwik Janowski ${ }^{14}$, poeta Tadeusz Miciński ${ }^{15}$ i publicysta Władysław Jabłonowski ${ }^{16}$. Wyruszył stąd na szerszy świat także i nasz Rudolf Szczękowski.

Jeszcze przed ukończeniem swego gimnazjum Dolo spotkał się z człowiekiem, który bardzo pozytywnie wpłynął na jego dalszy rozwój. Był to ksiądz Jan Ścisławski ${ }^{17}$, szeroko już znany na Podolu i Wołyniu, wówczas proboszcz w pobliskim Fastowie ${ }^{18}$, który odwiedzając niekiedy Białą Cerkiew, zwrócił uwagę na wybitnie zdolnego chłopaka i otworzył mu swój dom i swoje serce, i odtąd Dolo, jak go zwano, swe wakacje zimowe i letnie spędza przeważnie na plebani

${ }^{10}$ Wojciechowska-Żywultowa 1939: 52-53.

${ }^{11}$ Niemirów (ukr. Неми́рів) - miasto na Ukrainie, na Podolu, siedziba władz rejonu niemirowskiego w obwodzie winnickim. Ludność - 11822 mieszkańców w 2016 r.

${ }^{12}$ Wojciechowska-Żywultowa 1939: 52-53.

${ }^{13}$ Jan Grzegorz Stanisławski (1860-1907) - polski malarz, wykładowca sztuki, inicjator i członek różnych ugrupowań artystycznych, jeden z głównych przedstawicieli polskiego modernizmu.

${ }^{14}$ Ludwik Janowski (1878-1921) - historyk kultury i oświaty. Studiował w Uniwersytecie Kijowskim, następnie na Uniwersytecie Jagiellońskim, doktorat w 1909, od 1912 docent. Por. Klinger 1922: 107-116.

${ }^{15}$ Tadeusz Miciński (1918-1918) - pisarz i poeta polski okresu Młodej Polski. Autor mistycznych powieści, poematów prozą i wierszy kontemplacyjnych. Jeden z czołowych pisarzy polskiego ekspresjonizmu, prekursor surrealizmu.

${ }^{16}$ Władysław Jabłonowski, pseud. Gryf, J.A. Błoński, St. Ostroga, Władysław Jab. (18651956) - polski krytyk literacki, nowelista, działacz polityczny, senator II kadencji (1928-1930) wybrany z listy Związku Ludowo-Narodowego w województwie łódzkim.

${ }^{17}$ Jan Ścisławski (1842-1910) - ksiądz katolicki, proboszcz kościoła Świętej Katarzyny w Petersburgu. Gimnazjum i seminarium ukończył prawdopodobnie w Kamieńcu Podolskim, początkowo pracował w parafiach diecezji kamienieckiej, w tym w Niemirowie. Por. Klinger 1910: 14.

${ }^{18}$ Fastów (ukr. Фастів) - miasto na Ukrainie, w obwodzie kijowskim. W 2006 r. miało około 50,9 tys. mieszkańców. Do XIX wieku oficjalna nazwa miasta to „Chwastów”. 
w Fastowie, gdzie ma do dyspozycji bogatą bibliotekę proboszcza, władającego głównymi językami Europy. W jego to mieszkaniu, przybywszy doń w odwiedziny jako były parafianin z Niemirowa, gdzie działał on poprzednio, spotkałem po raz pierwszy Dola, uczącego się na gwałt francuskiego, gdyż proboszcz inaczej jak po francusku mówić z nim nie chciał. Tak zawarta znajomość zbudziła wzajemną sympatię, prowadzącą do trwałej przyjaźni. Mój nowy znajomy, mający wkrótce otrzymać maturę, zamierzał wstąpić na Uniwersytet Kijowski, $\mathrm{i}$ ten sam zamiar żywiłem wówczas ja, po nieudanych - z różnych powodów próbach studiowania w Petersburgu oraz w Krakowie ${ }^{19}$. Cieszyłem się wielce, że będę z nim razem chodzić na wykłady, cieszyłem się tym bardziej, gdy przyjechawszy do Kijowa zastałem już tam Dola, lecz była to radość krótka, bo jeszcze przed rozpoczęciem wykładów Dolo znikł z Kijowa bez pożegnania i wszelkich wyjaśnień, i dopiero po długim czasie dowiedziałem się, że urządził się gdzieś indziej i inaczej niż było w planie, a plan rozbił się o szkopuł materialny.

U wuja jego, mającego na utrzymaniu kilku naraz siostrzeńców, na studia wyższe dla Dola zabrakło, rzecz naturalna, pieniędzy, i Dolo dla zdobycia na to własnych środków przyjął na cały rok stanowisko nauczyciela prywatnego w obywatelskim domu państwa Bernatowiczów ${ }^{20}$ na Podolu. Chciano go zatrzymać dla wychowania syna jedynaka na dłuższy czas, oparł się on jednak, pociągany przez studia dalsze, lecz gdy przyszło znów do wyboru uczelni, to urok dalekiej, lecz milszej jego sercu Warszawy, okazał się tym razem silniejszy od czarów geograficznie bliższego, lecz uczuciowo dalszego Kijowa. Z punktu widzenia dalszych studiów tego wyboru nie można w żadnym razie uznać za słuszny, gdyż w owych czasach Uniwersytet Warszawski - o ile przynajmniej chodziło o nauki humanistyczne - wśród uniwersytetów rosyjskich zajmował bezsprzecznie miejsce ostatnie. Ocena taka nie jest bynajmniej podpowiedziana przez uprzedzenia polskie, lecz opiera się na sądzie niezależnej publicystyki rosyjskiej, że wspomnę choćby o książce Nikołaja Dubrowskiego Oficjalnaja nauka w Carstwie Polskom (Warszawkij Uniwieristiet po licznym wospominanijam $i$ wpieczatlenijam ${ }^{21}$. Nie zamierzam oczywiście twierdzić, że uniwersytet ten nie posiadał wcale $\mathrm{w}$ ciągu swego istnienia wybitnych uczonych i wykładowców, tylko ci bardziej wartościowi jego przedstawiciele nie czując się w Warszawie u siebie, traktowali zawsze swój tam pobyt jako chwilowy i stanowiący odskocznię do dalszej kariery, i spieszyli się co rychlej przenieść się

${ }^{19}$ „Studia uniwersyteckie wypadły mi widać pod złą gwiazdą: rozpoczęte na wydziale historyczno-filologicznym w Petersburgu przerwałem z powodu choroby, która mnie zmusiła do powrotu na południe; zacząwszy je po raz drugi na wydziale filozoficznym w Krakowie, musiałem wkrótce uchodzić do Rosji przed groźbą odbywania służby wojskowej w armii pruskiej”. Cyt. za: Klinger 2015: 155.

${ }^{20}$ Bernatowicze herbu Aksak, wylegitymowani w Cesarstwie Rosyjskim i zapisani do ksiąg szlachty1858 r. Por. Uruski 1904: 144.

${ }^{21}$ Dubrowski 1908. 
do miast rosyjskich jak Petersburg i Moskwa, Kijów i Odessa, a choćby nawet Kazań i Charków, a w Warszawie zostawali tylko ci, którzy nie mieli warunków do dalszego awansu. Taki na przykład filolog klasyczny jak profesor Sänger ${ }^{22}$, uczony o solidnym dorobku naukowym, umysł o szerokich zainteresowaniach intelektualnych, pozwalających mu z jednej strony zajmować się owocnie poetami polsko-łacińskimi i wysuwać trafne poprawki skażonego tekstu, z drugiej zaś strony dawać w pięknej mowie łacińskiej przekłady poetów XIX wieku, jak Mickiewicz, Wiktor Hugo, Musset i inni, które odbijane na osobnych kartkach rozsyłał tylko przyjaciołom i znawcom (takie ulotki widywałem w ręku moich mistrzów kijowskich i filologa warszawskiego Michała Rowińskiego ${ }^{23}$, z którym utrzymywał on kontakty towarzyskie) - na krótko tylko zajaśniał na horyzoncie warszawskim, aby nieco później objąć tekę ministra oświaty w Petersburgu; w okresie zaś studiów Szczękowskiego w Warszawie filologia klasyczna przedstawiała się tam bardzo ubogo i skromnie. Z trzech jej przedstawicieli, którymi byli grecysta Nasonow i dwaj latyniści, Wiachow i Baziner ${ }^{24}$, jedynie ten ostatni mógł się legitymować pewnym, choć nie tak wielkim dorobkiem naukowym: rosyjska bibliografia prac dotyczących filologii klasycznej, wydana w 1898 r., a więc w czasie, kiedy Szczękowski w Warszawie uczyć się zaczynał, zaznacza zaledwie dwa artykuły Bazinera, z których jeden odnosi się do dziejów myśli greckiej, a drugi do historii Macedonii ${ }^{25}$, milczy jednak o poprzednio wymienionych. Widocznie przy obsadzie katedr rozstrzygały tu względy nie tylko naukowe, ile polityczne, a nawet... familijne: wszak nieposiadający prac Nasonow otrzymał katedrę filologii w Warszawie chyba dzięki temu, że był krewnym profesora zoologii na Uniwersytecie Warszawskim ${ }^{26}$. Prawdopodobnie i Oskar Baziner zawdzięczał swe stanowisko nie tyle swym pracom naukowym, ile nadmiarowi (mimo swego pochodzenia niemieckiego) patriotyzmu rosyjskiego, z jakim w 1905 r. w czasie wielkiego strajku politycznego w Rosji jako listonosz zastępował strajkujących pocztowców, a może także niepozbawionej znaczenia okoliczności, że był zięciem słynnego znawcy łaciny archaicznej Franza Büchelera $^{27}$. Nie ulega wątpliwości, że mieli oni wszyscy rite odbyte studia filologicz-

${ }^{22}$ Grigorij Edwardowicz Zenger (właśc. Sänger, 1853-1919) - filolog klasyczny, profesor Uniwersytetu Warszawskiego i jego rektor w latach 1897-1899, członek korespondent akademii nauk, minister oświaty Cesarstwa Rosyjskiego.

${ }^{23}$ Michał Rowiński (1860-1925) - polski teoretyk literatury, pedagog, wykładowca Uniwersytetu Warszawskiego, członek Towarzystwa Naukowego Warszawskiego.

${ }^{24}$ Oskar Fiodorowicz (Basiner) Baziner (1867-1909) - filolog klasyczny, profesor Uniwersytetu Warszawskiego. Autor m.in. pracy Ludi saeculares. Driewnierimskija siekuliarnyja igry. Istoriko-fitologiczeskoje issledowanije z 1901 roku.

${ }^{25}$ Pozorow 1898: 47; 174.

${ }^{26}$ Nikołaj Wiktorowicz Nasonow (1855-1939) - rosyjski zoolog, w latach 1889-1905 profesor Uniwersytetu Warszawskiego.

${ }^{27}$ Franz Bücheler (1837-1908) - niemiecki filolog klasyczny, uczeń Friedricha Ritschla (1806-1876), profesor uniwersytetu w Bonn. 
ne, niemniej jednak pewnym było i to, że wiedzy w młodości nabytej później nie pogłębili. O ileż lepiej, poważniej przedstawiała się tedy filologia klasyczna na Uniwersytecie Kijowskim, gdzie z trzech jej przedstawicieli antyku dwaj, a mianowicie Adolf Sonny ${ }^{28}$ i Julian Kułakowski ${ }^{29}$ byli to znani z licznych prac w kraju i za granicą uczeni: pierwszy filolog utrakwista ${ }^{30}$, piszący po łacinie, niemiecku i rosyjsku, drugi historyk republikańskiego i cesarskiego Rzymu oraz Bizancjum, trzeci wreszcie Józef Lecius ${ }^{31}$, mniej produktywny uczony, był za to pierwszorzędnym wykładowcą, doskonale orientującym słuchaczy co do ówczesnego stanu przedstawianej przezeń nauki. Czuło się tu surową, ale i podniecającą zarazem atmosferę myśli badawczej, nastrajającej odpowiednio młode umysły, czego brakło w tym czasie na Wydziale Historyczno-Filologicznym w Warszawie, i właśnie tam u jednego ze wspomnianych profesorów, grecysty Nasonowa, wypadło Szczękowskiemu pisać tak zwaną ,pracę kandydacką”, wieńczącą studia i dającą prawo nauczania w szkole średniej. Dotyczyła ona jednego (nie pamiętam jakiego) dialogu Platona i polegała na przygotowaniu możliwie wiernego przekładu i dobrze wprowadzającej doń przedmowy, co mu się z powodzeniem udało, że jednak tego typu przewodnicy nie mogli zaspokoić bardziej wymagającej części słuchaczy, pragnącej nie tylko dyplomów, ale pogłębionej wiedzy, operującej nowymi metodami i prowadzącej do wciąż nowych zwycięstw i odkryć, lecz mogli raczej ich zrażać i odstręczać, zrozumieć nietrudno. Szczękowski jednak od raz obranego antyku odstręczyć się nie dał, lecz kierownictwa i metody naukowej poszukiwał gdzie indziej, a mianowicie wśród historyków, gdzie właśnie w tym czasie wysunął się na plan pierwszy mediewista Pietruszewski ${ }^{32}$, i na wykłady jego oraz seminaria gorliwie uczęszczał. Nic więc nie ma dziwnego, że po otrzymaniu dyplomu i zdobyciu na to środków (prawdopodobnie w formie jakiegoś stypendium) podążył za przenoszącym się mistrzem do Moskwy. Tak więc z najgorszego w Rosji uniwersytetu przeniósł się wprost do bodaj najlepszego, gdzie studia historyczne stały bardzo wysoko. Obok Pietruszewskiego działali tu ludzie tej miary, jak przedstawiciel historii

${ }^{28}$ Adolf Sonny (1861-1922) - doktor filologii greckiej, profesor Uniwersytetu Kijowskiego, rzeczywisty radca stanu. Por. Puczkow 2011. Witold Klinger zadedykował pamięci profesora Sonny swoją pracę Przyczynki do fragmentów tetrametrycznych Archilocha (Poznań 1923).

${ }^{29}$ Julian Andriejewicz Kułakowski (1855-1919) - doktor filologii łacińskiej, zasłużony profesor zwyczajny Uniwersytetu Kijowskiego, członek korespondent Cesarskiej Rosyjskiej Akademii Nauk, ojciec Sergiusza (1892-1949), rusycysty, docenta Uniwersytetu Łódzkiego. Por. Puczkow 2004; Klinger 2004: 445-453.

${ }^{30}$ System nauczania polegający na używaniu dwu języków wykładowych.

${ }^{31}$ Josif (Ernst) Andriejewicz Lecius (1860-1931) - filolog klasyczny, profesor Uniwersytetu Kijowskiego.

${ }^{32}$ Dmitrij Moisiejewicz Pietruszewski (1863-1942) - rosyjski historyk mediewista, profesor nadzwyczajny Uniwersytetu Warszawskiego od 1897 r., profesor zwyczajny od 1902 r., profesor Uniwersytetu Moskiewskiego od 1906 roku. 
powszechnej Winogradow ${ }^{33}$, który po katedrze w Moskwie otrzymał katedrę w Oksfordzie, gdzie działał aż do śmierci, jak słynny Kluczewski ${ }^{34}$, odsłaniający z bezwzględną otwartością wszystkie tajemnice politycznego życia Rosji, i wreszcie Kiesewetter ${ }^{35}$, oświetlający procesy jej społeczno-politycznego bytowania. Studiów tych z powodu braku środków Szczękowski nie doprowadził do końca i musiał wracać nad Wisłę, wynosząc o tamtejszym uniwersytecie jak najlepsze wspomnienie jako imponującym ośrodku twórczej myśli naukowej, pracującym w warunkach nieprawdopodobnej wręcz wolności słowa.

Pracę pedagogiczną w kraju Szczękowski rozpoczyna w Siedlcach, gdzie jednak nie pozostawał długo: w czasie wielkiego strajku politycznego w Rosji, który w 1905 r. zmusił Mikołaja II do ogłoszenia konstytucji, widzimy go już w Warszawie. Tu praca idzie mu dobrze i życie układa się pomyślnie. Piękny, wspaniale zbudowany młodzieniec o kruczoczarnych włosach i smutnych oczach, kontrastujących dziwnie z wesołym, dowcipnym żartem na ustach i miłym tonie głosu, jest doskonałym, pociągającym wykładowcą, umiejącym zainteresować słuchaczy nawet tak niepopularnymi i zbędnymi przedmiotami, za jakie powszechnie uważa się języki starożytne. Staje się też rychło cenioną siłą pedagogiczną. Nie potrzebuje już sam ubiegać się o lekcje, gdyż teraz raczej szkoły muszą ubiegać się o niego, a przy tym zarówno męskie jak i żeńskie. Nie będę wyliczał wszystkich szkół, które pracą swą obsługiwał, gdyż lista ta jest długa i obejmuje szkoły najbardziej cenione. W tych warunkach mógł zarabiać $\mathrm{i}$ istotnie zarabiał stosunkowo dużo.

Skończyła się konieczność liczenia się z każdym groszem i tułaczka po wynajmowanych jak najtaniej ,pokojach z samowarem” i trzeciorzędnych pensjonatach. Może się już jako tako przyodziać i kupować sobie książki, zdobywa się wreszcie na własne dwupokojowe mieszkanie z kuchnią, w której króluje poważna ,pani Franciszkowa”, zamieszkała w suterenach tegoż domu. To jego mieszkanie zresztą staje się wkrótce bezpiecznym hotelem dla wszystkich wędrujących kolegów z bliska i z daleka. Muszę o tej jego szerokiej gościnności tu wspomnieć, bo i sam z niej w 1920 r. szeroko korzystałem. Przybywszy wprost z głodującego Kijowa i mając za cały majątek pelerynę i okrągłe pudło drewniane, zawierające zamiast kapeluszy nieco bielizny, rękopisów i odzieży, udałem

${ }^{33}$ Paweł Gawryłowicz Winogradow (ang. Paul Vinogradoff, 1854-1925) - rosyjski historyk mediewista, profesor zwyczajny Uniwersytetu Moskiewskiego, od 1903 r. profesor katedry prawa porównawczego uniwersytetu w Oksfordzie.

${ }^{34}$ Wasilij Osipowicz Kluczewski (1841-1911) - rosyjski historyk. W latach 1882-1909 był profesorem uniwersytetu w Moskwie. Członek Petersburskiej Akademii Nauk. Zajmował się historią społeczno-gospodarczą i rozwojem instytucji przedstawicielskich w Rosji XVI-XVIII w. Dzieje Rosji przedstawiał jako proces rozwoju grup społecznych, których rola i wzajemne stosunki zmieniały się w zależności od warunków ekonomicznych i życia politycznego kraju.

${ }^{35}$ Aleksander Aleksandrowicz Kizewetter (1866-1933) - rosyjski historyk, publicysta i działacz polityczny. W 1922 r. wysłany ze Związku Sowieckiego, osiedlił się w Pradze, gdzie wykładał w Rosyjskim Instytucie Prawniczym i na Uniwersytecie Karola. 
się wprost $\mathrm{z}$ dworca do biura adresowego $\mathrm{w}$ ratuszu po adres brata ${ }^{36}$ mojego i Szczękowskiego, i odtąd cały czas dzieliłem między jednym i drugim. Praca pedagogiczna nie pochłaniała go jednak całkowicie, nie zaspakajała jego potrzeb intelektualnych, jego tęsknoty bijącego żywym tętnem życia umysłowego.

Pamiętam, jak latem 1906 r., pod koniec moich studiów monachijskich, ujrzałem go niespodziewanie na korytarzu uniwersytetu, przybyłego razem z gronem młodych naukowców z Warszawy, korzystających z wcześnie zaczynających się wakacji rosyjskich, aby zakosztować coś niecoś z najświeższych zdobyczy nauki niemieckiej. Do grona tego poza Szczękowskim należeli historyk Michał Kreczmar ${ }^{37}$, prawnik Stefan Łukasz Ehrenkreuz ${ }^{38}$, a także przybyły z Kijowa Henryk Jakubanis. Zaglądając do Niemiec, interesował się on także działalnością naszych uniwersytetów w Galicji i słuchał przygodnie wykładów Morawskiego ${ }^{39}$. Przy tym szacunku do nauki i intelektu ludzkiego nawiedzała go niekiedy tęsknota do ciszy i ukojenia, jakie daje głębokie życie duchowe, $\mathrm{i}$ oto parę lat potem dowiedziałem się, z własnych ust jego, że odbył także z inną grupą intelektualistów wycieczkę do Ziemi Świętej, i nawet w pewnym „hospicjum" francuskim, gdzie przyjęto ich bardzo serdecznie, zaimponował swoim towarzyszom podziękowaniem pożegnalnym, w nieskazitelną szatę francuską przybranym: fastowskie przeszkolenie u ks. Ścisławskiego wytrzymało więc próbę czasu. Jak z przytoczonych przykładów wynika, nie należał on do ciułaczy składających swe oszczędności do skarbonki. Raczej przeciwnie, był on jednym z tych, do których można zastosować słowa Jana Chryzostoma Paska o królu Janie Kazimierzu: „Jako pan był dobry, nigdy nie miał szczęścia do pieniędzy. Po prostu nie chciały się go trzymać" ${ }^{40}$. Po miesiącach thustych przychodziły więc nieraz także chude. Pewną skłonność do rozrzutności, zastanawiającą u człowieka z klasy mieszczańskiej, skłonny jestem tłumaczyć przykładem rosyjskiej inteligencji pracującej, która nieraz zarabiając wiele, lubiła czasem się popisać pogardą dla „podłego kruszcu” („priezrienyj mietałł”), w ten swoisty sposób walcząc z kapitalizmem.

Nie mając więc szczęścia do pieniędzy, miał go znacznie więcej do ludzi, którzy przeważnie odnosili się doń bardzo życzliwie. Kochała go młodzież za jego jasny wykład, bardzo często okraszony humorem, za jego przystępność

${ }^{36}$ Ludwik Jan Cyryl Klinger (1872-1939) - prawnik.

${ }^{37}$ Michał Kreczmar (1881-1939) - polski historyk.

${ }^{38}$ Stefan Łukasz Ehrenkreutz (1880-1945) - polski historyk prawa, profesor i ostatni rektor (od 1939 r.) Uniwersytetu Stefana Batorego w Wilnie, działacz Polskiej Partii Socjalistycznej, zwolennik linii politycznej Józefa Piłsudskiego, senator III i IV kadencji (1930-1938) II Rzeczypospolitej, wolnomularz.

${ }^{39}$ Kazimierz Morawski (1852-1925) - polski filolog klasyczny, historyk, profesor i rektor Uniwersytetu Jagiellońskiego, prezes Polskiej Akademii Umiejętności, kandydat na urząd Prezydenta RP. Odznaczony Orderem Orła Białego.

${ }^{40}$ Pasek 1923; 1929: 321-322. 
i sprawiedliwość, a nade wszystko za jego płynącą z serca dobroć. Lubiła go szczerze za jego zalety, choć lubiła także pośmiać się czasem z jego wcześniej zauważonych słabości. Spostrzeżono na przykład, że nieraz się spóźniał na pierwszą, to jest najwcześniejszą lekcję, co było naturalnym skutkiem przeciągających się długo w noc lektur, i oto, gdy nadchodził dzień i godzina odpowiednia, młodzież przed lekcją tłumnie zbierała się przy oknach i patrzyła w tę stronę, z której zwykle przybywał profesor, i często spotykała ją wielka radość: w głębi ulicy ukazywał się popędzający cwałującego konia dryndziarz, którego z kolei z tyłu popędzał profesor. Lubili go także koledzy wykładowcy za niezmiennie poprawny do nich stosunek, za absolutny brak pyszałkowatości, zawiści i karierowiczostwa, co tak często zatruwa współżycie koleżeńskie, a nade wszystko za jego stałą gotowość podzielenia się z potrzebującym tym, co posiadał sam. Lubiło go i ceniło starsze pokolenie, jak Stefan Cybulski ${ }^{41}$ oraz Tadeusz Zieliński $^{42}$, któremu po pierwszym przybyciu do kraju i przed wżyciem się w stosunki warszawskie, początkowe osamotnienie osładzał i którego książkę o kulturze greckiej na język polski przełożył, przyczyniając się do udostępnienia publiczności polskiej jego bogatego dorobku rosyjskiego. Nie lubili go natomiast dyrektorowie i dyrektorki szkół za nieugiętość, sztywność karku i nieumiejętność milczącego przystosowania się do wskazań odgórnych. Nie psuło to jednak stosunku doń Ministerstwa Oświecenia, które nie tylko mianowało go lektorem języka greckiego na Uniwersytecie Warszawskim, ale co więcej, mianowało go instruktorem nauczania języków starożytnych, zobowiązanym do dozorowania i podciągania do należytego poziomu ich wykładowców. Dowiedziałem się o tym przypadkiem, gdy przyjechawszy do Krakowa na posiedzenie Polskiej Akademii Umiejętności, spotkałem niespodziewanie Szczękowskiego w restauracji po dokonaniu takiego „podciągnięcia”, i okazało się, że ten instruktor miał zwyczaj osładzać nauczycielom gorzkość swych uwag i pouczeń przez końcową wspólną kolację na koszt oczywiście pana instruktora. Takich wyjazdów w teren dokonywał on wtedy niemało i niemało musiały go one kosztować. Przeziębiwszy się w czasie jednej z wycieczek instruktorskich, nabawił się choroby nerek, która - choć mu niekiedy folgowała - nie opuściła go już nigdy.

Najazd niemiecki, który zniszczył II Rzeczypospolitą, nie oszczędził miłego mieszkania na rogu Litewskiej i Szucha, z widokiem na Aleje Ujazdowskie, i kulturalnego życia, które tu płynęło. Gdym w styczniu 1940 r. przekradł się z żoną ${ }^{43}$ do spustoszonej Warszawy, nie od razu doszedłem do własnego pokoju

\footnotetext{
${ }^{41}$ Stefan Cybulski (1858-1937) - filolog klasyczny. Por. Polski Słownik Biograficzny, Kraków 1938, IV, 118.

${ }^{42}$ Tadeusz Stefan Zieliński, pseudonim Eheu (1859-1944) - polski historyk kultury, filolog klasyczny, profesor Uniwersytetu w Petersburgu i Uniwersytetu Warszawskiego, członek Polskiej Akademii Umiejętności. Por. Klinger 1974: 501-514.

${ }^{43}$ Raisa Klinger, z domu Bakkalińska (1889-1978) - absolwentka Kijowskich Wyższych Kursów dla Kobiet. Przez jej siostrę Wierę (1898-1979) Witold Klinger był spowinowacony
} 
i nawiązania kontaktów z przyjaciółmi. Nie prędko więc dowiedziałem się, że jest znowu chory na nerki i leży w Czerwonym Krzyżu ${ }^{44}$. Odwiedziłem go tam dwukrotnie. Za pierwszym razem zastałem go już w lepszej formie: wierzył w rycerską Francję i jaśniejsze jutro, i dodawał sobie i mnie humoru złośliwościami czytanego właśnie Heinricha Heinego pod adresem dobrej matki Germanii ${ }^{45}$. Podczas drugiej wizyty chodziłem już z nim na spacer. Surowa zima przerwała ledwie nawiązane stosunki. Począłem znów bywać w nowym jego schronieniu, w oficynie w modrzewiowym podwórzu, gdzie widziałem jeszcze nieco jego książek, gdzie przeżywał on załamanie się Francji i związanych z nią nadziei i gdzie odwiedzała go już jakaś nauczycielka, doradzająca wyjazd na lekcje na wieś i obiecująca zaopiekowanie się biblioteką. Istotnie wyjechał, aby zniknąć na długo, i pojawił się dopiero w jesieni, był u nas i skarżył się na kuchnię wiejską, która - jak mówił - szkodzi. Słyszałem, że parę razy zmieniał miejsce pobytu, zanim pojawił się znowu w Warszawie. Razu pewnego w zimie spotkaliśmy się rano koło Placu Narutowicza: ja z wiązką drewna na opał, on z podobnie prozaicznym bagażem, i obaj byliśmy mało skłonni do zwierzeń. Nie wiedziałem, niestety, że to jest spotkanie ostatnie. W jesieni 1943 r. z przerażeniem dowiedziałem się od doktora Gordziejewa ${ }^{46}$, byłego asystenta Tadeusza Zielińskiego, o powrocie Szczękowskiego ze wsi w stanie ciężkim, i umieszczeniu go w szpitalu św. Rocha ${ }^{47}$. Nie mogłem, związany pracą, w tej chwili się wybrać do niego, a gdy to już było możliwe, przyszła katastrofa. Od profesora

z czeskim filologiem klasycznym prof. Frantiskiem Novotnym (1881-1964), a przez drugą siostrę Zinaidę (1895-1969) z rosyjskim teologiem prof. Wasylem Ekzemplarskim (1875-1933).

${ }^{44}$ Szpital Czerwonego Krzyża w Warszawie znajdował się przy ul. Smolnej 6. Jest to murowany zabytkowy budynek z XIX w. Do 5 sierpnia 1915 r. istniał tutaj szpital Rosyjskiego Czerwonego Krzyża. Po wkroczeniu wojsk niemieckich do stolicy, budynek przejął Polski Komitet Pomocy Sanitarnej. 18 stycznia 1919 r. powołano Polskie Towarzystwo Czerwonego Krzyża i szpital pozostał w dyspozycji Towarzystwa. 1 września 1927 została zmieniona nazwa na Polski Czerwony Krzyż, i szpital należał PCK. Działalność szpitala została przerwana w czasie powstania warszawskiego, kiedy to budynki zostały zniszczone i spalone. Obecnie w budynku mieści się Klub Bankowca.

${ }^{45}$ Heine 1956: 499-575.

${ }^{46}$ Włodzimierz Gordziejew (25 X 1909, Moskwa-?) - polski filolog klasyczny, syn Rosjanina Aleksandra i Polki Elżbiety z domu Puchalska; w 1928 r. ukończył Gimnazjum im. Księcia Józefa Poniatowskiego w Warszawie (ul. Nowolipie 8) i rozpoczął studia w UW; 23 II 1932 r. uzyskał dyplom magisterski (Nr 821/3540/32) na podstawie pracy „Tacyt jako psycholog” (Archiwum UW, teczka Nr RP 28218) i został asystentem prof. Tadeusza Zielińskiego. Autor m.in.: Ludi scaenici et circenses quid in rebus publicis antiquorum valuerint, Warszawa 1936; Quaestionum de Iulii Pollucis fontibus caput, Warszawa 1936; De prologo Thesmophoriazusarum, Lwów 1937; De prologo Acharnensium, Lwów 1938; O prologach Arystofanesa = De prologis Aristophaneis, Warszawa 1939. Teczka osobowa Włodzimierza Gordziejewa nie zachowała się w zespole akt MWRiOP (informacja AAN w Warszawie z 17 IX 2018 r.).

${ }^{47}$ Szpital św. Rocha w Warszawie - założony w 1710 r. przy ul. Krakowskie Przedmieście 24, początkowo prowadzony przez Bractwo św. Rocha. Działał przez około 208 lat. Podczas II wojny światowej gmach szpitala został spalony. Po wojnie został częściowo odbudowany, bez kaplicy. 
Saskiego ${ }^{48}$, który zdążył go jeszcze odwiedzić w szpitalu, a potem kierował pogrzebem, wiem, że choć lekarze uważali stan jego za beznadziejny, nie cierpiał bardzo i zasnął spokojnie. Spoczywa na Powązkach i ma grób własny, zaopatrzony w imię, nazwisko i datę śmierci.

Tyle zachowała moja pamięć o życiu, studiach i działalności wychowawczej Zmarłego. Zastanawiając się nad wynikami jego życiowych zmagań, nie można się opędzić uczuciu dotkliwego żalu. Rzucał on niewątpliwie pełną garścią dobre i zdrowe ziarno, które przynosiło później błogie owoce, ale rzucał je wyłącznie w słowie mówionym, nie zaś utrwalającym działanie słowie pisanym. Dlaczego tak się stało, starałem się już to wyjaśnić: rosyjscy profesorowie antyku w Warszawie nie nadawali się na kierowników młodego adepta tej dyscypliny, zmuszonego do szukania dyrektyw u przedstawicieli katedr pokrewnych, ci zaś, operując materiałem odmiennym, mogli dawać tylko ogólnie orientujące wskazania, nie zaś rady ułatwiające podejście do problemów konkretnych, i pozostawiony samemu sobie Szczękowski mógł być tylko pociągającym popularyzatorem, nie zaś samodzielnym badaczem. Niezaprzeczalną jednak jego zasługą jest, że działając w okresie powstawania, rozwoju i zwycięstwa polskiej szkoły średniej, nigdy nie podzielał tej powierzchownej i błędnej ideologii, która stała się bodaj głównym źródłem jej słabości. Ponieważ szkoła ta powstała w ogniu walki z grecko-łacińskim gimnazjum rosyjskim, sądzono niemal powszechnie, że język grecki w szkole średniej ma może uzasadnienie w Rosji, która cywilizację chrześcijańską otrzymała z greckiego Bizancjum, w Polsce natomiast, która wzięła ją z łacińskiego Rzymu, konieczna jest jedynie łacina, $\mathrm{i}$ w rezultacie takiego rozumowania nasze ceniące rzekomo antyk gimnazjum humanistyczne przyszło na świat w postaci okaleczonej czy niedokształconej. Szczękowski natomiast bronił zawsze prymatu antyku greckiego przed rzymskim, jako postaci jego pierwotnej i doskonalszej, a więc o większej wartości wychowawczej: wszak nawet politycznie zwycięski Rzym uległ w końcu cywilizacyjnej wielkości Hellady.

Cicho i niepostrzeżenie dobiegło kresu życie Henryka Jakubanisa, od września 1920 r. profesora filozofii na jedynym w Polsce uniwersytecie katolickim, zmarłego 7 kwietnia 1949 r. o godzinie 10 wieczorem w szpitalu sióstr szarytek w Lublinie ${ }^{49}$. Żadne ogłoszenie drukowane nie zawiadomiło mieszkańców

Obecnie znajduje się tutaj księgarnia, a jedyną pamiątką, która pozostała po szpitalu, jest krzyż, który znajduje się nad wejściem.

${ }^{48}$ Stanisław Saski (1884-1963) - dr nauk medycznych, bakteriolog. Cf. Polski Stownik Biograficzny, Kraków 1994, XXXV, s. 258.

${ }^{49}$ Siostry szarytki posługiwały w Lublinie w następujących szpitalach: w szpitalu św. Wincentego a Paulo przy ul. Poczętkowskiej (obecnie ul. Staszica), w szpitalu św. Józefa (obecnie ul. 
tego miasta o dniu i godzinie jego pogrzebu, żaden nekrolog nie podniósł jego zasług naukowych i pracy wychowawczej, nie wspomniał o jego długotrwałym więzieniu na zamku lubelskim ${ }^{50}$ (od 9 listopada 1939 do 15 marca 1940 r.) i mężnej oraz niezachwianej postawie w czasie przesłuchań przez Gestapo, nie opowiadał o katastrofalnym dlań, przez lekkomyślność ludzką spowodowanym wydarzeniu (najechanie na chodniku przez jadącą z niedozwoloną szybkością rowerzystkę), którego skutkiem było najprzód ciężkie poranienie głowy, później zaś rosnące trudności mowy, odcinające go krok za krokiem od świata żywych, i wreszcie o jego kilkuletnim powolnym konaniu z zupełną pogodą i rezygnacją. Jeżeli głucho było o tym w Lublinie, gdzie nawet niektórzy przywiązani doń uczniowie o śmierci profesora dowiedzieli się już po pogrzebie, to cóż dopiero mówić o innych ośrodkach życia polskiego, gdzie także o zgonie tym panowało całkowite, lecz jakże niezasłużone milczenie. Zmarły bowiem nie był byle kim, jakąś postacią bladą i nic nieznaczącą, nad którą można było łatwo przejść do porządku dziennego. „Strasznie zasmuciła mnie wiadomość o śmierci kochanego H. Jakubanisa" pisał 30 czerwca zeszłego roku jeden z jego dawnych kolegów kijowskich; „Zgon drogiego kolegi H. Jakubanisa jest wielkim ciosem dla tych niedobitków, którzy jeszcze żyją z naszego kijowskiego grona", donosi z Warszawy inny pod datą 5 maja 1949 r., wreszcie obu im wtóruje z Torunia pod datą 5 maja tegoż roku jeszcze inny, wyrażając głęboki żal, że zmarłemu „nie danym było pomimo wielkich zdolności i stałości upodobań naukowych osiągnąc tego, co mógł".

Z pochodzenia Litwin, syn wychodźcy z kowieńszczyzny, który w poszukiwaniu pracy znalazł się aż w głębokiej Rosji, Henryk Jakubanis przyszedł na świat 14 marca 1879 r. w osadzie fabrycznej Kulebaki ${ }^{51}$ w guberni Niżny Nowogród, gdzie ojciec jego Jan aż do śmierci zajmował skromne stanowisko ekonoma fabrycznego. Dzięki matce, z domu Matulanis, która wcześnie przylgnęła do kultury polskiej, w domu Jakubanisów panował język polski, i uderzający niekiedy żartobliwie w nutę literackiej dumy narodowej młody Henryk znajomości języka litewskiego już nie posiadał. W gimnazjum klasycznym w Jełat'mie ${ }^{52} \mathrm{w}$ guberni tambowskiej, do którego ceniący oświatę rodzice skie-

Radziwiłłowska), szpitalu Dzieciątka Jezus oraz w szpitalu św. Jana Bożego przy ul. Lubartowskiej 81.

${ }^{50}$ Zamek w Lublinie - zamek królewski w Lublinie, zbudowany w XII w., wielokrotnie przebudowywany, w latach 1831-1954 wykorzystywany jako więzienie, od 1957 r. siedziba Muzeum Lubelskiego.

${ }^{51}$ Kulebaki - rosyjskie miasto leżące $188 \mathrm{~km}$ na południowy wschód od Niżnego Nowodordu, centrum administracyjne. W 2010 r. liczyło 25759 mieszkańców.

${ }^{52}$ Jełat'ma (ros. Елатьма) - osiedle typu miejskiego w Rosji, nad rzeką Oką. Pierwszy raz wzmiankowane w 1381 r., od 1779 r. ośrodek administracyjny namiestnikostwa tambowskiego, w XIX w. miasto powiatowe w guberni tambowskiej. Pod koniec XIX w. znajdowało się tam gimnazjum i 12 cerkwi. Ośrodek ożywionego handlu zbożem, a także konopiami, miodem i woskiem. W 1880 r. miasto liczyło 7107 mieszkańców. 
rowali swego jedynaka za cenę dużych ofiar materialnych, idącym przez szkołę wpływom rusyfikacyjnym skutecznie przeciwdziałał nauczyciel łaciny, Polak Boelke, i nie tylko w ciągu kilku lat udzielał mu systematycznych lekcji języka i literatury polskiej, a nawet wziął od niego uroczyste słowo, że wierszy rosyjskich pisać nie będzie, do czego - zachęcany przykładem kolegów - miał wielką skłonność, zwłaszcza odkąd przekład jego jednej z ballad Heinego, odczytany na dorocznym akcie gimnazjum, przyniósł mu powszechny aplauz. Wcześnie więc wyróżnił się tam zdolnościami i licząc zaledwie lat osiemnaście uzyskał maturę w 1897 r., nagrodzony nadto złotym medalem. Rodzice, zachęceni tak pięknym przykładem, za cenę dalszych wyrzeczeń postanowili skierować syna na uniwersytet, na przekór sceptycznym głosom sąsiadów Polaków („Cóż to? Chcecie państwo Henryka na profesora kształcić?"), i wybór ich padł nie na bliską Moskwę, lecz na znacznie dalszy Kijów głównie dlatego, że tu „synowi łatwiej będzie o towarzystwo polskie". Tutaj też w jesieni 1897 r. na parterze gmachu uniwersyteckiego, stanowiącym wyłączną domenę Wydziału Historyczno-Filologicznego, ujrzałem po raz pierwszy kolegę Henryka. Był to wówczas piękny młodzieniec, wysoki i z ładnie sklepioną głową i wysokim czole, bujnych ciemnych włosach, oczach błękitnych i żywych rumieńcach. Z zajmującą powierzchownością łączył on przy tym duże zalety towarzyskie: uprzejmość, rozmowność i wielki dar prowadzenia sporów, w których ujawniał niepospolitą wymowę. Zyskał więc bez trudu przychylność kolegów mimo, że nie dzielił nigdy ich szeroko rozpowszechnionych rozrywek i przyjemności, a niebawem, już po pierwszych ćwiczeniach łacińskich i greckich zwrócił także na siebie uwagę kierowników naszych, profesorów Juliana Kułakowskiego, Aleksego Nikitycza Giljarowa $^{53}$, Józefa Leciusa i Adolfa Sonny'ego. Znacznie starszy odeń wiekiem (miałem już za sobą dwa zmarnowane lata na nieudaną wyprawę po naukę do Petersburga i Krakowa, gdzie nie udało mi się utrzymać), nawiązałem z nim rychło stosunek przyjazny, który wytrzymał próbę czasu i przetrwał niezachwiany aż do samego końca współżycia i współpracy naszej w Kijowie, to jest do 1920 roku. Wdzięczne wspomnienie o nim daje mi możność przedstawienia dalszego ciągu jego zmagań życiowych mimo, że od trzeciego roku studiów drogi nasze się rozeszły. Ja pozostałem przy filologii klasycznej, on związał się ściślej z filozofią.

Wielkie zdolności młodzieńca dzięki jego zapałowi i umiejętnemu kierownictwu wymienionych profesorów, rozwijały się pomyślnie i egzaminy przejściowe z pierwszego roku na drugi były szeregiem niczym niezmąconych sukcesów. Na drugim już roku otrzymuje on stypendium rządowe, przysługujące mu do końca studiów obranych, który jednak nastąpił nie w 1901 r., jak było to przewidziane, lecz dopiero w 1902 r., a to z tej przyczyny, że na skutek nadmiernej

${ }^{53}$ Aleksy Nikitycz Giljarow (1856-1938) - rosyjski filozof, literaturoznawca i pedagog. Od 1887 r. wykładowca Uniwersytetu Kijowskiego, w 1891 r. został profesorem. 
pracy związanej z podjęciem rozprawy konkursowej na wysunięty przez profesora Giljarowa temat („Nieśmiertelność dusz u Platona”) wplątał się w ciężką chorobę płuc, która po leczeniu klinicznym wymagała dłuższej kuracji klimatycznej na Krymie. Rozprawa więc jako niedostarczona przez niego w terminie z góry wyznaczonym z powodów formalnych nagrody otrzymać nie mogła, niemniej jednak przedstawiona wydziałowi w charakterze pracy kandydackiej w połączeniu ze świetnym wynikiem egzaminów państwowych, odbytych pod przewodnictwem profesora Tadeusza Zielińskiego, spowodowała pozostawienie go przy Katedrze Historii Filozofii w charakterze tak zwanego „stypendysty profesorskiego" na trzy lata, a tymczasem dała mu możność pracy w kijowskich szkołach średnich, gdzie wykładał on logikę, psychologię, historię starożytną oraz autorów łacińskich i greckich. Przyjęcie tych bardzo obciążających prac było nakazem konieczności, pozostając w związku z przedwczesną śmiercią ojca i obowiązkiem zaopiekowania się pozostałą rodziną, to jest matką i nieletnią siostrą, które przybywają teraz do Kijowa. Lekcje te zresztą zamienia w 1903 r. na stanowisko wychowawcy dwóch synó ${ }^{54}{ }^{k s i e ̨ c i a ~ E u g e n i u s z a ~ T r u b i e c k o j a ~}{ }^{55}$, profesora Uniwersytetu Kijowskiego, później zaś Moskiewskiego, a przyjaciela Mariana Zdziechowskiego ${ }^{56}$, i na tym stanowisku pozostaje on do przeniesienia się księcia z Kijowa do Moskwy, kiedy to obejmie Jakubanis analogiczne stanowisko wychowawcy przy uczącym się w Kijowie młodzieńcu z Litwy o nazwisku Narwojsza. Od 1907 r. prowadzi on zlecone wykłady filozofii na Kijowskich Wyższych Kursach dla Kobiet. W 1908 r. po zdaniu egzaminów magisterskich i wygłoszeniu dwóch wykładów pro venia legendi, zostaje docentem filozofii na Uniwersytecie Kijowskim. Jego dalej zajmowane stanowisko wychowawcy młodego Narwojsza daje mu możność odbywania wraz z wychowankiem zagranicznych podróży wakacyjnych, w toku których w latach 1906-1909 zwiedził on Niemcy, Austrię, Czechy, Węgry, Belgię, Szwajcarię i Włochy Północne. W następnym, 1910 r., zostaje wysłany przez cesarskie Ministerstwo Oświaty na dalsze studia filozoficzne za granicę na okres dwóch i pół roku, w toku których poznaje główne ośrodki myśli fillozoficznej najpierw w Niemczech (Berlin, Jena, Lipsk, Heidelberg i Monachium), później we Włoszech (Rzym, Bolonia), gdzie ma okazję uczestniczenia w międzynarodowym kongresie filozoficznym.

${ }^{54}$ Siergiej Jewgieniewicz książę Trubieckoj (1890-1949) - wykładowca Uniwersytetu Moskiewskiego, w 1922 r. zmuszony do emigracji. Pozostawił wspomnienia Minuwszeje, Moskwa 1991; Aleksander Jewgieniewicz książę Trubieckoj (1892-1968).

${ }^{55}$ Eugeniusz Nikołajewicz książę Trubieckoj (1863-1920) - rosyjski filozof, prawnik, publicysta i działacz społeczny. W 1889 r. ożenił się z księżniczką Wierą Szczerbatową, z którą miał troje dzieci: Siergieja, Aleksandra i Zofię. Jest autorem m.in. książki Kolorowa kontemplacja. Trzy szkice o ikonie ruskiej (Białystok 1998).

${ }^{56}$ Marian Ursyn Zdziechowski herbu Rawicz (1861-1938) - polski historyk idei i literatury, filolog, filozof, krytyk literacki i publicysta, rektor Uniwersytetu Stefana Batorego w Wilnie, członek Zjednoczenia Państwowego na Kresach w 1922 r., założyciel Unii Narodowo-Państwowej w 1922 r., w latach 1933-1938 prezes Towarzystwa Przyjaciół Nauk w Wilnie. 
Niestety, przemęczenie nie pozwoliło mu wykorzystać w pełni wolnego od trosk rodzinnych okresu (matka już od dawna nie żyła, siostra zdążyła skończyć konserwatorium), zmuszając do wypoczynku w sanatorium. W styczniu 1913 r. jest już znów na Ukrainie i po kilkumiesięcznych wczasach u przyjaciół Markiewiczów na wsi, z początkiem 1914 r. wznawia swą pracę tak na uniwersytecie, jak i na wyższych kursach oraz na niektórych później powstałych uczelniach, jak na przykład w istniejącym od 1916 r. Polskim Kolegium Uniwersyteckim w Kijowie, kierowanym przez naszego kolegę profesora Ludwika Janowskiego (zmarłego w 1922 r. w Wilnie). Jednak w niespokojnych czasach pierwszej wojny światowej nie było warunków systematycznej i owocnej pracy naukowej. Dość powiedzieć, że z początkiem jesieni 1915 r. Uniwersytet Kijowski wraz z jego olbrzymią biblioteką, profesorami, docentami został ewakuowany do Saratowa ${ }^{57}$. Henryk Jakubanis dzieli ten exodus swego uniwersytetu z brzegów Dniepru na brzegi Wołgi, gdzie oczywiście nauka, uprawiana na biwaku, prosperować nie mogła, i pustka zaległa piękny gmach, gdzie jako pierwsi wykładali niegdyś wysłani tu Krzemieńczanie i Wilnianie. Po roku dopiero następuje powrót relegowanego uniwersytetu, lecz atmosfera jest wciąż niespokojna. W 1917 r., po przewrocie lutowym Henryk Jakubanis wybrany zostaje profesorem nadzwyczajnym filozofii na Uniwersytecie Kijowskim. W 1918 r. po dalszych wstrząsach i zaciętych walkach ulicznych na tle zatargu między władzą państwową a dążącą do niepodległości Ukraińską Centralną Radą ${ }^{58}$, przychodzą do Kijowa Niemcy i ustanawiają rządy hetmana Skoropadskiego ${ }^{59}$. Rok ten jednak oprócz okupantów niemieckich sprowadził do Kijowa także emisariuszy litewskich z Kowna, zapraszających profesora Jakubanisa na Katedrę Filozofii do stołecznego Uniwersytetu Litewskiego, a propozycja ta została bardzo grzecznie przyjęta, załatwiona była jednak odmownie. Katedrę więc w Kijowie zachował aż do rozwiązania przez władze sowieckie dawnego uniwersytetu i wyższych kursów dla kobiet, to jest do 1919 r., aby zostać z kolei profesorem na Uniwersytecie Ukraińskim i wykładać jednocześnie w różnych tworzonych wówczas instytutach, takich jak archeologiczny, muzyczny, oraz brać udział w przedsięwzięciach Ukraińskiej Akademii Nauk ${ }^{60}$, jak na przykład w Encyklopedii Ukraińskiej. Po traktacie ryskim w końcu stycznia 1922 r. przekracza jako

\footnotetext{
${ }^{57}$ Saratów - miasto w Rosji, port rzeczny nad Wołgą.

${ }^{58}$ Ukraińska Centralna Rada (ukr. Українська Центральна Рада) - paraparlamentarny organ państwowy, reprezentacja Ukrainy wyłoniona po rewolucji lutowej w Rosji. Po przewrocie bolszewickim suwerenny organ państwowy Ukraińskiej Republiki Ludowej.

${ }^{59}$ Pawło Skoropadski (1873-1918) - ukraiński polityk i wojskowy. Hetman Państwa Ukraińskiego od 29 kwietnia 1918 do 26 grudnia $1918 \mathrm{r}$.

${ }^{60}$ Akademia Nauk Ukrainy (ukr. Національна академія наук України, НАНУ) - najwyższa państwowa badawcza organizacja na Ukrainie. Powstała w 1918 r., kiedy została podpisana przez hetmana Państwa Ukraińskiego Pawła Skoropadskiego ustawa ustanawiająca Ukraińską Akademię Nauk. Jednym z jej zadań jest regulowanie języka ukraińskiego. Zajmuje się również naukami humanistycznymi oraz naukami podstawowymi.
} 
repatriant granicę polską razem z siostrą swoją po dwutygodniowej podróży w czasie najsroższych mrozów i znajduje się w stanie pożałowania godnym: wiem coś o tym, bo z trudem odnalazłszy ich na twardej pryczy kasarnianej ${ }^{61}$ w Równem ${ }^{62}$, musiałem prowadzić długie pertraktacje $\mathrm{z}$ władzami o skrócenie terminu stosowanej kwarantanny. Po wyleczeniu się w Warszawie w domu brata mojego, otrzymał powołanie do Lublina i pracował w nim, póki sił mu starczyło, pod opieką zaś brata mego znajdował się aż do jego śmierci.

Wybuch drugiej wojny światowej zaskoczył go w domu wypoczynkowym dla profesorów w Świdrze vulgo Mądralinem ${ }^{63}$ zwanym. W tej odciętej od świata placówce pozostawał wraz z siostrą tak długo, aż chłód, głód i brak światła zmusiły go do powrotu do Lublina, w braku innej komunikacji najętymi końmi, otulonego z braku ciepłego płaszcza w zwyczajną kołdrę watową. Tak dostał się w końcu do swego mieszkania, gdzie właśnie za pozwoleniem - oczywiście władz uniwersyteckich, znalazł przygodny przytułek jeden z niezliczonych wówczas wędrujących Polaków, znakomity pisarz, a obecnie profesor Uniwersytetu Katolickiego, Jan Parandowski ${ }^{64}$, któremu zawdzięczam znajomość wspomnianych szczegółów. Ten powrót do domu był jednak tylko krótkim wytchnieniem po jednej próbie, a przed drugą, o wiele cięższą: już 9 listopada zamknęły się za nim drzwi więzienne na starym zamku lubelskim, z którego wyszedł dopiero 15 marca 1940 r. Próba wreszcie trzecia, najcięższa, która przyszła - rozumiem tu owo nieszczęsne najechanie na ulicy - pochłonęła resztkę sił, tkwiących jeszcze w biednym, skołatanym ciele. Co prawda, po kilkumiesięcznej kuracji w szpitalu pozornie ozdrowiały profesor zgłosił raz jeszcze po wygnaniu okupantów gotowość do dalszej pracy uniwersytecie, lecz przecenił on tutaj swoje fizyczne siły, pogarszające się w szybkim tempie braki wymowy uniemożliwiły mu rychło prowadzenie wykładów. Ostatnie lata życia były już jednym pasmem coraz bardziej dotkliwych cierpień. Kiedy widziałem go po raz ostatni w czerwcu

\footnotetext{
${ }^{61}$ Kasarnia - koszary, przeniesione (pod wpływem właśnie wyrazu kasarnia, niem. Kaserne, z romańskiego, a to w końcu od łac. casa - chata) z owczarni, bo koszara, dawniej koszarza, poszła z rumuńskiej (macedońskiej) kaszare - zagroda dla owiec (z łac. casearia - od nazwy sera). Por. Brückner 1912: 260.

${ }^{62}$ Równe (ukr. Piвне) - miasto na Ukrainie, stolica obwodu rówieńskiego i rejonu rówieńskiego. W okresie międzywojennym miasto powiatowe w II Rzeczypospolitej; W 1939 r. liczyło 41 500 mieszkańców (w tym 21000 Żydów i 15000 Polaków) i było największym miastem województwa wołyńskiego ze stolicą w Łucku.

${ }^{63}$ Dom Pracy Twórczej „Mądralin” Polskiej Akademii Nauk znajduje się przy ul. Mlądzkiej w Emowie (wieś położona w Mazowieckim Parku Krajobrazowym i rezerwacie przyrody Świder); dom powstał około 1921 roku. Projektantem budynku był architekt Jan Witkiewicz Koszczyc (1881-1958), a fundatorem parku - Stanisław Hiszpański, który w 1922 r. przekazał Kasie im. J. Mianowskiego, z zaleceniem utworzenia tam domu dla literatów oraz uczonych. Z czasem przylgnęła nazwa Mądralin - od siedziby mędrców.

${ }^{64}$ Jan Parandowski (1895-1978) - polski pisarz, eseista i thumacz literatury, autor Mitologii. W latach 1945-1950 kierownik Katedry Kultury Antycznej, a następnie literatury porównawczej na Katolickim Uniwersytecie Lubelskim.
} 
1947 r., można było jeszcze żywić co do przyszłości złudzenia: w atmosferze wspomnień młodości chory sam odmłodniał, rozpogodził się i ożywił, i pomimo trudności wymowy, usuwanej z pomocą rozumiejącej go lepiej siostry, miało się chwilami wrażenie, że widzi się jeszcze dawnego Henryka. Zawiodły jednak prędko nadzieje wiązane najprzód $\mathrm{z}$ zastosowaniem hydroterapii według metody dr. Żniniewicza ${ }^{65}$ z Poznania, później zaś z farmakopeą szeroko znanego leczącego ziołami księdza spod Dęblina. Upadek sił postępował ciągle. Od roku z powodu słabości nóg nie opuszczał mieszkania, od trzech miesięcy nie wstawał z łóżka. Od stycznia 1949 r. nawet siostra przestała go rozumieć i porozumiewać się mogli tylko na piśmie. Na dwa dni przed śmiercią przeniesiono go do szpitala sióstr szarytek, w którym świątobliwie, opatrzony sakramentami, żywota dokonał. W tych ostatnich dniach chciał coś pisać, gwałtownie upominał się o papier i ołówek. Sama śmierć przyszła już jako łagodna oswobodzicielka, bez agonii, w cichym śnie przecinając nić zbyt męczeńskiego życia.

Takie były vices et fata, to znaczy zmienne przypadki i koleje oraz zastygłe już w niezmiennym i nienaruszalnym kształcie losy życiowe, poczynając od pierwszych porywów i wzlotów przez dalsze zdobycze i stopniowe przybieranie na siłach aż do zwycięskiego wkroczenia na wykreślony przez jego talent i zdobytą wiedzę teren pracy i wreszcie aż do czasów najstraszliwszej narodowej i osobistej klęski, stanowiącej przyczynę jego załamania się fizycznego, lecz bynajmniej nie duchowego. Bliższe pojęcie o rodzaju, kierunku i zasięgu jego działalności akademickiej przyniesie zainteresowanym krótkie i bynajmniej niewyczerpujące zestawienie opracowanych i wygłoszonych przezeń kursów, które wymownie świadczy o rozpiętości jego zainteresowań naukowych i rozległości terenów, przeoranych jego myślą badawczą, wykładał on bowiem nie tylko wstęp do filozofii i historii filozofii starożytnej od jej najwcześniejszych początków do późnego schyłku, lecz także logikę, estetykę i etykę - niezmiernie pouczające zestawienie - z którego wynika jasno, że dla filozofa kijowskiego prawda nie była czymś od dobra i piękna oderwanym, lecz tworzyła z nim razem żywą i organiczną całość. Oprócz takich kursów ogólnych prowadził on także kursy specjalne, poświęcone wielkim twórczym postaciom albo doniosłym przełomowym okresom w rozwoju myśli filozoficznej, jak na przykład „Presokratycy”, „Platon”, „Metafizyka Arystotelesa”, „Pitagorejczycy” i tym podobne ${ }^{66}$. Wykłady te przy tym nie były odczytywaniem z papierka skrzętnie zebranego, lecz martwego materiału erudycyjnego: stanowiły one raczej głos żywy do umysłu żywych zwrócony i wzywający je do samoistnego szukania prawdy w oparciu o zdobycze myśli starożytnej. I wołanie to nie pozostało bez

${ }^{65}$ Jan Norbert Żniniewicz (1872-1952) - balneolog, pionier nowoczesnej akwaterapii w Polsce.

${ }^{66}$ Zachowały się: Noty z wykładów na Wyższych Polskich Kursach Naukowych w Kijowie, rękopis 1917-1918 (Biblioteka Narodowa w Warszawie). 
echa, młody docent zdobył sobie od razu wśród młodzieży ogromną popularność. Wykłady jego odbywały się w największych, jakie były do dyspozycji, salach, które zawsze wypełniały się po brzegi, i zostawiały po sobie trwałe i głębokie wrażenie - i jeżeli na Wydziale Matematyczno-Fizycznym najbardziej czarował słuchaczy profesor Siewiercow ${ }^{67}$, to na Wydziale Historyczno-Filologicznym czynił to z niemniejszym sukcesem docent Jakubanis. Tak było in illo tempore w Kijowie.

$\mathrm{Na}$ temat lubelskiego okresu działalności Zmarłego niewiele, niestety, posiadam wiadomości ${ }^{68}$. Zakres przerabianych materii pozostał, o ile mi wiadomo, taki sam, jednak nie było już tu tak ścisłego zespolenia i zżycia nauczającego $\mathrm{z}$ nauczanymi. Profesora Jakubanisa $\mathrm{w}$ tym okresie widywałem, niestety, rzadko i krótko, i choć ani w rozmowach ani w listach nigdy się nie skarżył, nie można było nie zauważyć, że jest jakby przygaszony i że w Lublinie nie czuje się dobrze. Nawykły do pracy na wielkim, dobrze wyposażonym uniwersytecie, do żywej wymiany myśli wśród kolegów i podniecającej atmosfery przepełnionych sal wykładowych, w cichym, małomiasteczkowym, często pozbawionym pomocy naukowych Lublinie czuł się on niekiedy jakby poza nawiasem życia naukowego, jakby na wygnaniu. Nie znajdując pełnego zadowolenia w pracy wykładowej, nie mógł on także w oparciu wyłącznie o własny, z Rosji szczęśliwie wywieziony księgozbiór, pogrążyć się w pracy ściśle badawczej, i nie spieszmy potępiać go za to, że w okresie lubelskim swego dorobku kijowskiego (mówię tu o dorobku drukowanym) prawie nie powiększył. Niech mi też nikt tu nie przypomina innych, w Lublinie pierwotnie działających profesorów filologii, jak Stefan Srebrny ${ }^{69}$ lub Mieczysław Stanisław Popławski ${ }^{70}$, którzy pomimo tych samych trudnych warunków zdobyli się na pokaźny dorobek naukowy: profesor Srebrny za czasów swej niedługiej lubelskiej działalności był zawsze jedną nogą w Warszawie, gdzie w domu ojca ${ }^{71}$ swego mając oparcie, mógł korzystać z wielkich bibliotek stołecznych; profesor Popławski, chory na płuca, musiał - aby czegoś dokonać - najgorętsze miesiące roku spędzać w Krakowie w Bibliotece Jagiellońskiej, za co zapłacił śmiercią przedwczesną. Profesor Jakubanis od obu wiekiem znacznie starszy i na zdrowiu coraz bardziej upadający, na ten heroizm zdobyć się już nie był w stanie, i z nadejściem ferii letnich lub zimowych musiał

${ }^{67}$ Aleksy Nikołajewicz Siewiercow (1866-1936) - rosyjski biolog, w latach 1902-1911 profesor zoologii Uniwersytetu Kijowskiego.

${ }^{68}$ Henryk Jakubanis w latach 1923-1925 był dziekanem Wydziału Nauk Humanistycznych, a poza tym przez wiele lat był opiekunem Koła Filozoficznego studentów KUL.

${ }^{69}$ Stefan Srebrny (1890-1962) - polski filolog klasyczny i tłumacz, znawca dramatu antycznego, w latach 1918-1923 wykładał filologię klasyczną na Uniwersytecie Lubelskim.

${ }^{70}$ Mieczysław Stanisław Popławski (1893-1946) - polski filolog klasyczny, historyk, w latach 1919-1946 profesor Katolickiego Uniwersytetu Lubelskiego.

${ }^{71}$ Stanisław (Samuel) Srebrny (?-?) - nauczyciel matematyki i urzędnik Towarzystwa Ubezpieczeniowego w Warszawie. 
szukać ulgi bądź w różnych uzdrowiskach, bądź w domu wypoczynkowym dla profesorów, we wspomnianym „Mądralinie”, gdzie w atmosferze koleżeńskiej odzyskiwał zwykle na czas jakiś dawną pogodę i stawał się duszą całego towarzystwa (informacja profesora Wachholza ${ }^{72} \mathrm{z}$ Krakowa). Nie dziwmy się więc, że dorobek drukowany profesora Jakubanisa jest ilościowo niewielki i sprowadza się niemal wyłącznie do wydanych jeszcze w Kijowie prac rosyjskich ${ }^{73}$. $Z$ tych prac największa objętością i doniosłością jest rozprawa o Empedoklesie, która składa się z obszernego wstępu oraz przekładu heksametrycznego wszystkich dochowanych fragmentów (z górą 600 wierszy), całkowicie przedrukowana $\mathrm{w}$ drugim tomie nowego rosyjskiego przekładu Lukrecjusza ${ }^{74}$ pióra poety Fiodora Pietrowskiego ${ }^{75}$. Z czasów lubelskich posiadamy jedynie recenzje prac polskich dotyczących Platona ${ }^{76}$.

Dziś oto my, ostatni koledzy i przyjaciele z lat dawnych, stoimy przed dokonanym już i na zawsze zamkniętym żywotem profesora Henryka Jakubanisa ze złożonym uczuciem nie tylko gorzkiej i piekącej straty, ale zarazem dręczącej niepokojącej zagadki. Ma się wrażenie, że jakieś niepojęte złe moce, chciwe i zawistne Harpie ${ }^{77}$ obdzierały tę bujną i bogato wyposażoną indywidualność zarówno z tego, co z natury jest przelotnym i krótkotrwałym, jak uroda, młodość, zdrowie, jak i z tego, co zwykle dziełu ludzkiemu zapewnia jako taką trwałość; rozumiem tu zdolność do pracy umysłowej i różniącą człowieka od bydlęcia mowę artykułowaną. Niepodobna opędzić się wrażeniu straszliwej niewspółmierności między zakrojonymi na miarę olbrzymią zamierzeniami a faktycznymi - według miernika pozycji bibliograficznych - aż nazbyt skromnymi osiągnięciami. Więc tak mało przynoszą czasami - nawet przy największych zdolnościach - sumienna praca, gorliwa uprawa umysłu i pełne wyrzeczeń, bezinteresowne poszukiwanie prawdy? Nie dajmy się jednak opanować tym myślom sceptycznym! Doniosłości dzieła życiowego prawdziwego działacza akademickiego - a takim był niewątpliwie Zmarły - nie mierzy się wyłącznie poziomym łokciem bibliograficznym, lecz posiewem rzucanych w dusze myśli

${ }^{72}$ Leon Jan Wachholz (1867-1942) - polski lekarz medycyny sądowej, jeden z najwybitniejszych polskich przedstawicieli tej dziedziny w XX w., autor pierwszych nowoczesnych podręczników medycyny sądowej, profesor UJ.

${ }^{73}$ 1) Echa platonizmu w liryce Fr. Schillera, 1904; Empedokles - filozof, lekarz i czarodziej, 1906 [1994²]; Doniostość filozofii starożytnej dla światopogladu wspótczesnego, 1910; Ocena sylogizmu w głównych momentach jego historii, 1910; Sprawozdanie z pracy naukowej zagranica w latach 1910-1912, 1913.

${ }^{74}$ Lukrecjusz, O prirodie wieszczej, przeł. F. A. Pietrowski, Moskwa 1936 (wielokrotnie wznawiane).

${ }^{75}$ Fiodor Aleksandrowicz Pietrowski (1890-1978) - rosyjski filolog klasyczny, wykładowca, znany tłumacz autorów starożytnych.

${ }^{76}$ Por. recenzję książki: Jordan 1938: 422-428.

${ }^{77}$ Harpie - w mitologii greckiej duchy (demony) porywające dzieci i dusze oraz uosabiające gwałtowne porywy wiatru. 
nowych, wielkich i szlachetnych, i wierzę głęboko, że w okresie największej siły swego talentu zdążył on wszczepić w umysły idącej za nim młodzieży takie umiłowanie prawdy, dobra i piękna, wobec którego niewiele chyba znaczą zdobycze myśli czysto erudycyjnej, wyrażające się w długich szeregach pozycji bibliograficznych ${ }^{78}$.

Jeżeli z tego punktu widzenia Zmarły nie potrzebuje usprawiedliwienia wobec Trybunału Najwyższego, który niewątpliwie uwzględni, że darowanych szczodrze talentów nie zakopał bezużytecznie $\mathrm{w}$ ziemi ${ }^{79}$, to potrzebuje on bezsprzecznie usprawiedliwienia wobec doczesnego sądu ludzkiego, który aż nadto pochopny jest mierzyć wartość uczonego wspomnianym sprawdzianem zewnętrznym. Zachodzą tu jednak różne okoliczności łagodzące, które tłumaczą aż nadto wystarczająco skromny poczet dzieł drukowanych. Bogata treść duchowa była w nim zawarta w naczyniu niezmiernie kruchym i wątłym. Pochodził on z rodziny dziedzicznie obciążonej: ojciec umiera wcześnie na serce, matka, licząca nie wiem czy lat sześćdziesiąt, z powodu choroby Basedowa, dającej się bardzo we znaki synowi i córce. Zwłaszcza za synem choroby różne chodzą w ślad niemal od dzieciństwa, aby w najważniejszych chwilach życia ujawniać swą siłę hamującą, na przykład w czasie egzaminów maturalnych, później podczas intensywnej pracy nad rozprawą konkursową, potem jeszcze w czasie egzaminów państwowych, wreszcie po przybyciu do Polski, kiedy przeziębiwszy się w czasie długiej podróży zimowej pociągiem repatriacyjnym, leczyć się musiał długo w mieszkaniu mojego brata w Warszawie. Do Polski przybył z siłami nadwątlonymi i nie można powiedzieć, żeby był od razu przyjęty życzliwie i serdecznie. Co prawda już w czasie pobytu u mego brata odbywała się tam długa defilada młodszych i starszych filozofów warszawskich, lecz do porozumienia między przybyszem z Kijowa i miejscowymi uczonymi nie doszło. Prawdopodobnie idealizujące nastawienie platonizującego przybysza nie bardzo odpowiadało stojącej na gruncie materializmu szkole warszawskiej, i do powołania na katedrę doprowadziły dopiero pertraktacje z Lublinem, wszczęte, o ile sobie przypominam, przez ojca Jacka Woronieckiego ${ }^{80}$. Do Lublina wyruszał z Warszawy profesor Jakubanis pełen najlepszej myśli, jak o tym świadczą przechowywane przez jego siostrę krotochwile, w nutę ludową uderzające wierszyki. Rzeczywistość jednak nie odpowiadała tym optymistycznym oczekiwaniom. W Lublinie

${ }^{78}$ Por.: „Henryk Jakubanis był tym profesorem KUL-u, który w okresie międzywojennym wywarł największy wpływ na kształcenie historyczno-filozoficzne. Szczególnie interesowała go filozofia starożytna, której znaczenie dla współczesnej kultury podkreślał. Przez wiele lat sprawował funkcję opiekuna Koła Filozoficznego”. Mróz 2013: 62.

${ }^{79} \mathrm{Mt} 25,18$.

${ }^{80}$ Jacek Woroniecki (1878-1949) - polski dominikanin, Sługa Boży Kościoła rzymskokatolickiego, teolog, pedagog, etyk, moralista i filozof-scholastyk. Wieloletni nauczyciel akademicki i profesor Wydziału Teologii Katolickiego Uniwersytetu Lubelskiego oraz Papieskiego Uniwersytetu Świętego Tomasza z Akwinu, rektor KUL w latach 1922-1924. 
nie znalazł w starszym już wieku profesor skromnego choćby aparatu naukowego i jeżeli jawnym niepodobieństwem dla władz uniwersyteckich było stworzyć dlań na poczekaniu wielkie i animujące koło słuchaczy, to powinny były one w stosunku do wyrzuconego burzą dziejową rozbitka zdobyć się na nieco więcej troski, więcej ciepła i serdeczności, brak których - jak wspomniałem - pędził go do tak zwanego „Mądralina”. Przykro jest o tym mówić zwłaszcza w naszych czasach, ale wydaje mi się, że jest coś z prawdy w gorzkich słowach profesora Jana Wilczyńskiego ${ }^{81}$, że Zmarły może być uważany za ofiarę otoczenia, które nie potrafiło otoczyć go opieką należytą i dać mu takich warunków, w których potrafiłby wykorzystać wszystkie siły i uzdolnienia ${ }^{82}$.

\section{BIBLIOGRAFIA}

Opracowania:

Brückner 1912: A. Brückner, Stownik etymologiczny języka polskiego, Warszawa 1912, 260.

Dąbkowski 1989: S. Dąbkowski, Profesorowie, dla których żywimy podziw i wdzięczność, w: Katolicki Uniwersytet Lubelski w latach 1925-1939 we wspomnieniach swoich pracowników i studentów, G. Karolewicz (red.), w: Materiały do Dziejów KUL, vol. II, Lublin 1989, 218.

Dąbrowski 1908: N. Dąbrowski, Oficjalnaja nauka w Carstwie Polskom (Warszawkij Uniwieristiet po licznym wospominanijam i wpieczatlenijam), Petersburg 1908.

Dziewulska 1989: F. Dziewulska, KUL byt drugim domem, w: Katolicki Uniwersytet Lubelski w latach 1925-1939 we wspomnieniach swoich pracowników i studentów, G. Karolewicz (red.), w: Materiały do Dziejów KUL, vol. II, Lublin 1989, 270.

Heine 1956: H. Heine, Niemcy - Baśń zimowa, przeł. J. Jankowski, w: Dzieła wybrane, A. Sowiński (red.), Warszawa 1956, 499-575.

Janeczek 2001: S. Janeczek, Filozofia na KUL-u. Nurty - osoby-idee, Lublin 2001, 29-30, 57.

Jordan 1938: Z. Jordan: O matematycznych podstawach systemu Platona (Poznań 1947, VI+328), „Przegląd Filozoficzny” 41 (1938), 4, 422-428. (recenzja).

Klinger 1910: W. Klinger, Ksiądz Jan Ścisławski: Wspomnienie pośmiertne, Kraków 1910, 14.

Klinger 1922: W. Klinger, Nieco wspomnień kijowskich o śp. profesorze Ludwiku Janowskim, «Przegląd Współczesny» 1(1922), 1-2, 107-116.

Klinger 1974: W. Klinger, Tadeusz Zieliński, w: Portrety uczonych polskich: 51 sylwetek humanistów, oprac. A. Biernacki, Kraków 1974, 501-514.

Klinger 2004: W. Klinger, Pamjati zastużennogo profiessora Kijewskogo uniwiersitieta, doktora rimskoj fiłołogii Ju. A. Kułakowskogo. Riecz, proizniesiena w zasiedanii Istoriczeskogo Obszczestwa Niestora-Letopisca 6 aprielja 1919 goda, w: A.A. Puczkow, Julian Kułakow-

\footnotetext{
${ }^{81}$ Jan Zygmunt Wilczyński (1891-1970) - profesor zoologii. Ukończył studia średnie w Kijowie z odznaczeniem i już w 1908 r. rozpoczął pracę w Zakładzie Biologii Uniwersytetu w Petersburgu. W 1919 r. wrócił do Polski i objął katedrę biologii w Uniwersytecie Stefana Batorego. 15 lipca 1945 r. został delegatem, a następnie kierownikiem prac i urzędu organizacyjnego Uniwersytetu Mikołaja Kopernika w Toruniu. W 1950 r., nie znajdując możności dalszej pracy naukowej, w czasie pobytu w Wielkiej Brytanii zdecydował się na emigrację i pracował w różnych uniwersytetach.

${ }^{82}$ Cf. Pastuszka 1949/1959: 344-346; Dąbkowski 1989: 218; Dziewulska 1989: 270; Kunowska 1989: 226-227; Pastuszka 1989: 126; Szewczyk 1989: 273-278; Wiśliński 1970: 200-203; Janeczek 2001: 29-30, 57; Mróz 2013: 43-71.
} 
skij i jego wriemja. Iz istorii antikowiedienija $i$ wizantinistiki w Rossii, Sankt-Petersburg, 445-453.

Klinger 2015: W. Klinger, Życiorys własny, „Symbolae Philologorum Poznaniensium” 25 (2015), $2,155$.

Korzeniowski 2009, M. Korzeniewski, Za Złota Brama. Działalność społeczno-kulturalna Polaków w Kijowie w latach 1905-1920, Lublin 2009, 229-251.

Kunowska 1989: M. Kunowska, Wspomnienia o profesorach KUL, w: Katolicki Uniwersytet Lubelski w latach 1925-1939 we wspomnieniach swoich pracowników i studentów, G. Karolewicz (red.), w: Materiaty do Dziejów KUL, vol. II, Lublin 1989, 226-227.

Mróz 2013: T. Mróz, Radiowa adaptacja Platonskich dialogów w przekładzie W. Witwickiego i jej recepcja na seminarium filozoficznym H. Jakubanisa w KUL, „Roczniki Filozoficzne” 51(2013), 1, 43-71.

Pasek 1923; 1929: J.Ch. Pasek, Pamiętniki, wydanie Jana Czubka, Kraków 1923;1929, 321-322.

Pastuszka 1949/1959: J. Pastuszka, Henryk Jakubanis (1879-1949) Wspomnienie pośmiertne, „Roczniki Filozoficzne” 2 (1949/1950), 2-3, 344-346.

Pastuszka 1989: J. Pastuszka, Wspomnienia o Katolickim Uniwersytecie Lubelskim z lat 19341939, w: Katolicki Uniwersytet Lubelski w latach 1925-1939 we wspomnieniach swoich pracowników i studentów, G. Karolewicz (red.), w: Materiaty do Dziejów KUL, vol. II, Lublin 1989, 126.

Pozorow 1898: P. Pozorow, Sistiematiczeskij ukazatiel knig i statiej po grieczeskoj filologii, Petersburg 1898, 47; 174.

Puczkow 2004: A.A. Puczkow, Julian Kułakowskij i jego wriemja. Iz istorii antikowiedienija $i$ wizantinistiki w Rossii, Sankt-Petersburg 2004.

Puczkow 2011: A.A. Puczkow, Adolf Sonni, Kijewljanin. K istorii kłasiczeskoj fiłołogii w Impieratorskom uniwiersitietie sw. Władimira, Kijów 2011.

Szewczyk 1989: M. Szewczyk, Vivat Academia, Vivant Professores!, w: Wspomnienia o Katolickim Uniwersytecie Lubelskim z lat 1934-1939, w: Katolicki Uniwersytet Lubelski w latach 1925-1939 we wspomnieniach swoich pracowników i studentów, G. Karolewicz (red.), w: Materiaty do Dziejów KUL, vol. II, Lublin 1989, 273-278.

Uruski 1904: S. Uruski, Rodzina. Herbarz szlachty polskiej, Warszawa 1904, 144.

Wiśliński 1970: J Wiśliński, Koło Filozoficzne (1919-1939), „Roczniki Filozoficzne” 18 (1970), $1,200-203$

Wojciechowska-Żywultowa 1939: J. Wojciechowska-Żywultowa, Biała Cerkiew. Książka pamiątkowa białocerkiewian, Warszawa 1939.

Zasztowt 2009: L. Zasztowt, Zapomniany Uniwersytet. Polskie Kolegium Uniwersyteckie w Kijowie (1917-1919), w: Europa Środkowo-Wschodnia a Rosja XIX-XX wieku. W kręgu edukacji i polityki, Warszawa 2007, 285-312.

\section{TWO FORGOTTEN PROPAGATORS OF ANTIQUITY IN 20TH-CENTURY POLAND}

Sum mary

Witold Klinger (1875-1962), Professor at the Poznań University between 1920-1959, wrote a memoir in the 1950s about his friends, classical philologists - Rudolf Szczękowski and Henryk Jakubanis. Klinger had earlier studied at the University of Kiev with both of them and lectured together with Henryk Jakubanis in Kiev. At that time, the article could not be published for ideological reasons. The grandson of Witold Klinger, Michał, has found this article in the family archive. It provides insight into his university life in Russia and interwar Poland. Rudolf Szczękowski 
joined the University of Warsaw after the First World War, where he was a Greek language teacher, whereas Henryk Jakubanis took a lecturing position of ancient philosophy at the Catholic University of Lublin. Both played a significant role in the life of these universities and both were forgotten. The article also expresses Witold's tribute to their difficult lives and scientific achievements, as well as their work on the intellectual development of students. 